\title{
Pengembangan Media Pembelajaran E-Learning Dengan Model Pembelajaran Flipped Classroom Berbasis Edmodo Pada Mata Pelajaran Informatika
}

\author{
Dedi Rahman ${ }^{1}$, P Wayan Arta Suyasa ${ }^{2}$, Dessy Seri Wahyuni ${ }^{3}$ \\ Program Studi Pendidikan Teknik Informatika \\ Universitas Pendidikan Ganesha \\ Singaraja, Indonesia \\ dedi.rahman@undiksha.ac.id ${ }^{1}$, arta.suyasa@undiksha.ac.id ${ }^{2}$, seri.wahyuni@undiksha.ac.id ${ }^{3}$
}

\begin{abstract}
The purpose of this study were (1) Produced a design and implemented the development of e-learning learning media with Edmodo-based Flipped Classroom model in Informatics subject of class VII in SMP Negeri 2 Mengwi, (2) Determined the subject teacher and students' responses towards the development of e-learning learning media with Edmodo-based Flipped Classroom model in Informatics subject of class VII in SMP Negeri 2 Mengwi. The study was a Research and Development $(R \& D)$ research with ADDIE development model. This study involved students from VII A class and teacher of Informatics subject in SMP Negeri 2 Mengwi. The method of data collection was questionnaire. The result of the study showed that (1) The design and the implemented e-learning media were success implemented based on validity test from content experts, design experts, and learning media experts with Aiken's V coefficient average score 0,89 and very valid, (2) The teacher and students' responses showed the average score were 40 for the teacher and 61,8 for the students, meaning that it was included in very positive category with very practical criteria.
\end{abstract}

Keywords: E-learning Learning Media, Flipped Classroom, Edmodo, Informatics

\section{PENDAHULUAN}

Dunia pembelajaran pada Abad 21 telah berkembang pesat seiring dengan perkembangan Teknologi Informasi dan Komunikasi (TIK). Berkaitan dengan itu, guru dituntut untuk memiliki kecakapan Abad 21, yang dikenal sebagai Kompetensi 4C (collaborative, communicative, critical, creative) agar mampu membawa peserta didiknya menjadi generasi yang kompetitif di era global Abad 21. Dalam melaksanakan tugas dan kewajibannya sebagai pengajar, guru perlu meningkatkan performasi dan kualitas pembelajarannya agar sejalan dengan kemajuan bidang TIK. Salah satu yang dapat dilakukannya adalah dengan mengubah pembelajaran cara lama menjadi pembelajaran cara baru yang dikenal sebagai E-Learning. Dengan E-Learning dapat dikembangkan pembelajaran modern yang mampu mengembangkan kemampuan kreatif, inovatif, kolaboratif, dan komunikatif pada diri peserta didik. Dengan tuntutan pembelajaran pada abad 21 tersebut, penggunaan course management system seperti edmodo sangatlah dibutuhkan dalam proses pembelajaran.

Berdasarkan observasi yang dilakukan di SMP Negeri 2 Mengwi, untuk mengetahui karakteristik peserta didik dan pembelajaran dilakukan dengan menyebarkan angket pada peserta didik kelas VII, dari hasil angket tersebut menunjukan bahwa guru belum memanfaatkan secara optimal fasilitasfaslitas yang ada untuk mendukung pembelajaran di sekolah seperti komputer, laptop, dan akses internet khususnya computer/laptop hanya digunakan ketika praktik saja. Peserta didik kesulitan untuk memahami materi yang disampaikan guru karena media yang digunakan tidak menarik dan selalu monoton. Keterbatasan waktu juga menjadi hambatan guru dalam menyampaikan materi pembelajaran di kelas sehingga guru kekurangan waktu dalam mengendalikan kelas. Dalam proses pembelajaran guru masih menggunakan metode konvensional dalam penyajian dan pendistribusian materi pelajaran dengan mengandalkan pertemuan tatap muka di dalam kelas. Hal ini dibuktikan dengan belum tersedianya media pembelajaran E-learning yang membantu peserta didik untuk bisa belajar mandiri melalui internet.

Berdasarkan hasil tersebut, dapat ditarik suatu analisis dasar bahwa proses pembelajaran di SMP Negeri 2 Mengwi, 
khususnya kelas VII pada mata pelajaran Informatika belum optimal. Hal ini disebabkan karena kurangnya pemanfaatan fasilitas pembelajaran yang ada disekolah, seperti penggunaan prasarana berupa laboratorium computer maupun laptop yang lengkap dengan koneksi internet. Oleh karena itu, dibutuhkan sebuah terobosan baru dalam meningkatkan kualitas pembelajaran melalui pembuatan media pembelajaran yang mempunyai integrasi dengan fasilitas pembelajaran yang ada. Media yang akan dipilih juga harus disesuaikan dengan kondisi peserta didik, karakteristik materi ajar, dan fasilitas yang tersedia. Salah satu media yang cocok dan memenuhi ketiga kriteria tersebut adalah media pembelajaran e-learning berbasis Edmodo. Kondisi peserta didik yang terkadang merasa bosan dengan media yang digunakan guru, membuktikan bahwa perlu dibuatkan sebuah media pembelajarann yang menarik. Kriteria materi pelajaran yang akan disajikan pun cocok bila ditampilkan dalam media e-learning.

Penelitian pengembangan e-learning berbasis edmodo sudah pernah dilakukan sebelumnya oleh peneliti lain yaitu penelitian yang dilakukan [1] menyatakan bahwa Penggunaan e-learning berbasis edmodo efektif untuk meningkatkan hasil belajar IPA pada peserta didik kelas VIII di SMP Negeri 2 Singaraja. Pada penelitian yang dlakukan oleh [2] yang menunjukan bahwa media pembelajaran $E$ Learning menggunakan Edmodo layak digunakan sebagai media pembelajaran. Selain itu, hasil penelitian Perbandingan Antara Model Pembelajaran Flipped Classroom Berbantuan Edmodo dengan Pembelajaran Konvensional yang telah dilakukan [3] menyatakan bahwa penggunaan model pembelajaran flipped classroom berbantuan edmodo lebih efektif daripada pembelajaran konvensional dalam meningkatkan hasil belajar peserta didik kelas X SMK Negeri 1 Banyudono.

Berdasarkan permasalahan yang dijabarkan tersebut, maka pembelajaran informatika kelas VII di SMP Negeri 2 Mengwi diperlukan pembelajaran yang bisa memadukan pembelajaran konvensional dengan pembelajaran online agar pembelajaran dapat memotivasi peserta didik dengan adanya media pembelajaran e-learning yang menarik, salah satunya dengan menggunakan model pembelajaran Flipped Classroom dengan menggunakan Platform Edmodo dalam rangka mendukung proses pembelajaran Informatika dan peneliti mengangkat dalam skripsi pengembangan dengan judul "Pengembangan Media Pembelajaran E-Learning dengan Model Pembelajaran Flipped Classroom Berbasis Edmodo pada Mata Pelajaran Informatika Kelas VII di SMP Negeri 2 Mengwi".

\section{LANDASAN TEORI}

\section{A. Media Pembelajaran}

Media pembelajaran adalah segala bentuk peralatan fisik maupun non fisik yang digunakan untuk menyampaikan informasi ke pembelajar atau peserta didik dalam rangka menunjang proses pembelajaran. media pembelajaran juga dipahami sebagai alat yang berfungsi untuk menyampaikan pesan pembelajaran.

\section{B. E-learning}

E-learning merupakan suatu sistem pembelajaran yang memanfaatkan teknologi untuk menghubungkan peserta didik dengan pendidik melalui koneksi internet untuk mempermudah dalam menyalurkan informasi. E-learning dalam praktiknya sering disebutkan sebagai pendidikan jarak jauh berbasis internet. Menurut [4] pendidikan jarak jauh merupakan pendidikan formal berbasis lembaga, di mana kelompok belajarnya terpisah, dan sistem telekomunikasi internet aktif digunakan untuk menghubungkan pembelajar, sumber belajar dan instruktur.

\section{Edmodo}

Edmodo merupakan platfrom media sosial yang sering digambarkan dengan facebook untuk kebutuhan sekolah dalam menunjang proses pembelajaran. [5] mengatakan bahwa Situs ini terihat mirip dengan facebook, namun lebih bersifat pribadi dan aman karena guru akan langsung membuat dan mengelola account, yang menerima kode kelompok yang dapat mengakses dan bergabung dengan group. Dengan menggunakan edmodo memungkinkan guru untuk berbagi konten, tugas, kuis, dan berkomunikasi dengan peserta didik. Edmodo dapat digunakan sebagai media pembelajaran untuk semua mata pelajaran yang tidak menggunakan aktivitas dan pengamatan secara langsung, untuk mata pelajaran ini edmodo digunakan sebagai pengantar teori maupun praktik sebelum peserta didik terjun pada aktivitas langsung di lab komputer.

\section{Model Pembelajaran Flipped Classroom}

Menurut [6] Flipped Classroom merupakan strategi yang dapat diberikan oleh pendidik dengan cara meminimalkan jumlah instruksi langsung dalam praktik mengajar mereka sambil memaksimalkan interaksi satu sama lain. Strategi ini memanfaatkan penggunaan teknologi yang menyediakan materi pembelajaran yang diakses secara online. Model pembelajaran ini memanfaatkan penggunaan teknologi yang menyediakan materi pembelajaran yang diakses secara online. Sebelum melaksanakan proses pembelajaran di kelas, terlebih dahulu guru akan menyuruh peserta didik untuk mempelajari materi yang akan diajarkan di kelas.

\section{E. Mata Pelajaran Informatika}

Informatika (Inggris: Informatics) merupakan disiplin ilmu yang mempelajari transformasi fakta berlambang yaitu data maupun informasi pada mesin berbasis komputasi [7]. Mata pelajaran Informatika merupakan perluasan dan pendalaman dari muatan TIK yang pada awal pemberlakuan Kurikulum 2013 yang penerapannya diintegrasikan kepada seluruh mapel melalui pembelajaran berbasis TIK. Dalam pedoman implementasi Muatan/Mata Pelajaran Informatika 
Kurikulum 2013, Kompetensi Informatika tidak hanya menjadikan peserta didik sebagai pengguna (user) dan konsumen saja, tetapi peseta didik lebih menekankan pada kemampuan mengidentifikasi persoalan-persoalan dan mengusulkan solusinya, kemudian secara kreatif dan inovatif menghasilkan produk-produk teknologi informasi sesuai dengan kaidah keilmuan informatika, rekayasa perangkat keras, perangkat lunak, dan pengolahan data dalam bentuk digital menjadi informasi.

\section{METODOLOGI PENELITIAN}

Penelitian ini merupakan jenis penelitian dan pengembangan atau dalam bahasa inggrisnya Research and Development (R\&D). penelitian ini bertujuan untuk mengembangkan media pembelajaran e-learning mata pelajaran informatika di SMP Negeri 2 Mengwi. Pengembangan Research and Development (R \& D) adalah metode penelitian yang digunakan untuk menghasilkan sebuah produk untuk di uji keefektifanya.

Model pengembangan media pembelajaran e-learning ini menggunakan model pengembangan ADDIE. Tegeh, dkk (dalam) menjelaskan ada 5 tahap dalam model pengembangan ADDIE, yaitu Analysis (analisis), Design (Desain), Development (Pengembangan), Implementation (Implementasi), dan Evaluation (Evaluasi). Pada Model ADDIE evaluasi dilakukan pada setiap tahap aktivitas pengembangan. Tahap evaluasi dilakukan terhadap kesatuan dan keseluruhan produk pengembangan berupa evaluasi formatif [8] Secara lebih jelas, tahapan Model ADDIE dapat dilihat pada Gambar 1.

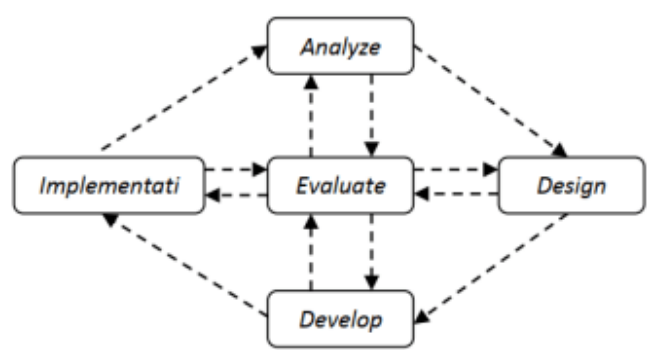

Gambar 1. Tahapan Model ADDIE [8]

\section{A. Prosedur Pengembangan Produk}

Prosedur pengembangan produk terdiri dari 5 tahap dengan mengikuti model ADDIE. Pada tahap pertama yaitu analisis, kegiatan utama yang dilakukan adalah menganalisis perlunya pengembangan media pembelajaran e-learning pada mata pelajaran Informatika. Setelah dilakukan analisis, langkah berikutnya adalah mendesain pembelajaran dengan berpedoman pada model pembelajaran flipped classroom. Untuk desain model pembelajaran flipped classroom terdiri dari 3 fase pembelajaran yaitu Before class, During class, dan After class. Sebelum masuk pada proses pembelajaran dengan model flipeed classroom guru melakukan kegiatan apersepsi guna memberikan pengarahan kepada peserta didik dan memastikan kesiapan peserta didik dalam menjalani proses pembelajaran. Pada fase before class guru akan membagikan materi di edmodo yang nantinya akan dipelajari oleh peserta didik di rumah sebelum pertemuan tatap muka di kelas (During class). Kemudian pada fases During class peserta didik lebih terlibat aktif dalam melakukan kegiatan diskusi atau mengerjakan LKPD yang dibimbing langsung oleh guru. Untuk fase After class guru melakukan kegiatan evaluasi kepada peserta didik dengan memberikan sebuah kuis maupun tugas untuk mengetahui tingkat pemahaman setiap kompetensi dasar yang dicapai. Selanjutnya tahap pengembangan dilakukan dengan mengembangkan rancangan yang diperoleh dari tahap desain media pembelajaran e-learning. Kemudian pada tahap implementasi, media pembelajaran e-learning ini akan diimplementasikan pada mata pelajaran Informatika kelas VII A. Pada tahap evaluasi peneliti akan melakukan evaluasi yang meliputi evaluasi formatif. Evaluasi formatif terdiri dari fase evaluasi ahli, evaluasi perorangan, evaluasi kelompok kecil, dan evaluasi lapangan.

B. Teknik Pengumpulan Data

Data yang dikumpulkan untuk dianalisis kualitatif dan kuantitatif dalam penelitian ini meliputi informasi karakteristik peserta didik dan pembelajaran, sumber belajar, kevalidan media pembelajaran e-learning, serta respons peserta didik dan guru terhadap media pembelajaran $e$ learning yang dikembangkan. Untuk lebih jelasnya dapat dilihat pada Tabel 1.

Tabel 1. Teknik Pengumpulan Data

\begin{tabular}{|c|c|c|c|}
\hline No Jenis Data & Metode & Sumber D & ata \\
\hline 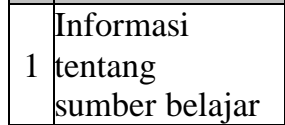 & Wawancar & $\begin{array}{l}\text { Guru Mata } \\
\text { Informatika. }\end{array}$ & Pelajaran \\
\hline $2 \begin{array}{l}\text { Karakteristik } \\
\text { Peserta Didik } \\
\text { dan } \\
\text { Pembelajaran }\end{array}$ & Angket & $\begin{array}{ll}\text { Peserta } & \text { didik } \\
\text { VII di } & \text { SMP } \\
\text { 2 Mengwi } & \end{array}$ & $\begin{array}{r}\text { kelas } \\
\text { Negeri }\end{array}$ \\
\hline $3 \begin{array}{l}\text { Kevalidan } \\
\text { Media } \\
\text { Pembelajaran E- } \\
\text { Learning }\end{array}$ & Angket & $\begin{array}{l}\text { a. Ahli } \\
\text { Pembelajaran. } \\
\text { b. Ahli } \\
\text { Pembelajaran. } \\
\text { c. Ahli } \\
\text { Pembelajaran. }\end{array}$ & $\begin{array}{r}\text { Isi } \\
\text { Desain } \\
\text { Media }\end{array}$ \\
\hline $4 \begin{array}{l}\text { Respons Peserta } \\
\text { Didik dan Guru }\end{array}$ & Angket & \begin{tabular}{|lll} 
Peserta & didik \\
VII di & SMP \\
2 Mengwi. & \\
\end{tabular} & $\begin{array}{r}\text { kelas } \\
\text { Negeri }\end{array}$ \\
\hline
\end{tabular}

1. Analisis Data Kevalidan Media Pembelajaran E-

Learning

Dalam memenuhi kriteria media pembelajaran $e$ learning yang valid berdasarkan penilaian validator, maka perlu dilakukan analisis data kevalidan dengan menggunakan 
e-ISSN: 2685-7006 | p-ISSN: $2252-9063$

Kumpulan Artikel Mahasiswa Pendidikan Teknik Informatika

(KARMAPATI)

Volume 10, Nomor 1,Tahun 2021

lembar validasi ahli. Kevalidan media pembelajaran $e$ learning ditunjukkan melalui uji ahli isi, ahli media, dan ahli desain yang kemudian dilanjutkan dengan melakukan uji perorangan, uji kelompok kecil, dan uji lapangan. Setelah melakukan uji tersebut, dilakukan perhitungan untuk menganalisis, revisi dan melakukan perbaikan terhadap media pembelajaran e-learning. Penilaian hasil dari uji ahli dihitung dengan Rumus Aiken[9]. Perhitungan validitas isi dengan rumus:

$$
\text { Validitas Isi }(\mathrm{v})=\frac{\sum \mathrm{s}}{\mathrm{n}(\mathrm{c}-1)}=
$$

Dimana :

$$
\begin{aligned}
& \mathrm{s}=\mathrm{r}-\mathrm{l}_{0} \\
& \mathrm{v}=\text { indeks kesepakatan rater mengenai validitas butir } \\
& \mathrm{r}=\text { skor yang diberikan oleh ahli (validator) } \\
& \left.\mathrm{l}_{0}=\text { skor penilaian validitas terendah (misalnya } 1\right) \\
& \mathrm{c}=\text { skor penilaian validitas tertinggi (misalnya } 5) \\
& \mathrm{n}=\text { banyaknya ahli (rater) }
\end{aligned}
$$

Tabel 2. Kriteria Tingkat Validasi Uji Ahli[10]

\begin{tabular}{|c|c|c|}
\hline $\begin{array}{c}\text { Koefisien } \\
\text { Validitas (v) }\end{array}$ & $\begin{array}{c}\text { Tingkat } \\
\text { Validitas }\end{array}$ & Kriteria \\
\hline $0,81-1,00$ & Sangat Tinggi & Sangat Valid \\
\hline $0,61-0,80$ & Tinggi & Valid \\
\hline $0,41-0,60$ & Cukup & Cukup \\
\hline $0,21-0,40$ & Rendah & $\begin{array}{c}\text { Kurang } \\
\text { Valid }\end{array}$ \\
\hline $0,00-0,20$ & Sangat Rendah & Tidak Valid \\
\hline
\end{tabular}

2. Uji Coba Perorangan, Kelompok Kecil, dan Lapangan

Rumus yang digunakan untuk menghitung persentase masing-masing subyek menurut [8] sebagai berikut:

Presentase $=\sum \frac{(\text { jawaban } \times \text { bobot tiap pilihan })}{n \times \text { bobot tertinggi }} \times 100 \%$

Keterangan:

$\sum=$ Jumlah

$\mathrm{n}=$ Jumlah seluruh item angket

Selanjutnya, untuk menghitung persentase keseluruhan subjek digunakan rumus sebagai berikut :

Persentase $=(\mathrm{F}: \mathrm{N})$

Keterangan:

$\mathrm{F}=$ Jumlah persentase keseluruhan subjek

$\mathrm{N}=$ Banyak subjek

Tabel 3. Konversi Tingkat Pencapaian Dengan Skala 5[11]

\begin{tabular}{|c|c|c|}
\hline $\begin{array}{c}\text { Tingkat } \\
\text { Pencapaian(\%) }\end{array}$ & Kualifikasi & Keterangan \\
\hline $90 \%-100 \%$ & Sangat Baik & Tidak perlu direvisi \\
\hline
\end{tabular}

\begin{tabular}{|c|c|c|}
\hline $75 \%-89 \%$ & Baik & Tidak perlu direvisi \\
\hline $65 \%-74 \%$ & Cukup & Revisi \\
\hline $55 \%-64 \%$ & Kurang & Revisi \\
\hline $0-54 \%$ & Sangat Kurang & Revisi \\
\hline
\end{tabular}

3. Analisis Data Respons Guru dan Peserta didik

Analisis data respons guru dan peserta didik dimaksudkan untuk mengetahui bagaimana respons guru dan peserta didik terhadap media pembelajaran e-learning dengan model pembelajaran flipped classroom berbasis edmodo yang dikembangkan. Data respons guru dan peserta didik secara klasikal dianalisis secara deskriptif. Perhitungan uji respons guru dan peserta didik dengan rumus[12]:

$$
\overline{\mathrm{X}}=\frac{\sum x}{N}
$$

Keterangan :

$\overline{\mathrm{x}}=$ rata - rata kelas untuk skor respons guru dan peserta didik

$\sum \mathrm{x}=$ Jumlah skor respons guru dan peserta didik

$\mathrm{N}$ = Banyaknya guru dan peserta didik

Tabel 4. Kriteria Penggolongan Respons Guru dan Peserta Didik[13]

\begin{tabular}{|c|c|c|}
\hline No & Interval & Katagori \\
\hline 1 & $\mathrm{Mi}+1,5 \mathrm{SDi} \leq \overline{\mathrm{x}}$ & Sangat positif \\
\hline 2 & $\mathrm{Mi}+0,5 \mathrm{SDi} \leq \overline{\mathrm{x}}<\mathrm{Mi}+1,5 \mathrm{SDi}$ & positif \\
\hline 3 & $\mathrm{Mi}+0,5 \mathrm{SDi} \leq \overline{\mathrm{x}}<\mathrm{Mi}+0,5 \mathrm{SDi}$ & Kurang positif \\
\hline 4 & $\mathrm{Mi}-1,5 \mathrm{SDi} \leq \overline{\mathrm{x}}<\mathrm{Mi}-1,5 \mathrm{SDi}$ & Negatif \\
\hline 5 & $\overline{\mathrm{x}}<\mathrm{Mi}-1,5 \mathrm{SDi}$ & Sangat Negatif \\
\hline
\end{tabular}

\section{HASIL DAN PEMBAHASAN}

Hasil akhir yang didapatkan dari penelitian yang telah dilakukan yaitu menghasilkan sebuah media pembelajaran $e$ learning dengan model pembelajaran Flipped Classroom berbasis Edmodo pada mata pelajaran Informatika kelas VII di SMP Negeri 2 Mengwi dengan menggunakan model ADDIE yang terdiri dari lima tahapan, yaitu analisis (analyze), desain (design), pengembangan (development), implementasi (implementation), dan evaluasi (evaluation). Pengujian media pembelajaran e-elarning dilakukan dengan uji validitas dan uji kepraktisan dimana uji validitas dilakukan dengan melibatkan para ahli, diantaranya ahli isi, ahli media dan ahli desain pembelajaran sedangkan uji kepraktisan dilakukan dengan uji coba perorangan, uji coba kelompok kecil, uji lapangan serta uji respons guru dan peserta didik. Pemaparan terkait hasil penelitian dan pengujian akan dijelaskan sesuai tahapan ADDIE:

\section{Hasil Tahap Analisis (Analyze)}

Hasil analisis karakteristik peserta didik, peneliti menyebarkan kuisioner ketika melakukan observasi awal. Dari hasil kuisioner diketahui bahwa peserta didik cenderung lebih senang belajar apabila terdapat gambar atau video 
pembelajaran yang membantu mereka memahami materi pelajaran serta forum diskusi untuk dapat bertanya langsung pada guru. Selanjutnya hasil dari analisis mata pelajaran Informatika terdapat beberapa standar kompetensi yang harus dicapai peserta didik yaitu Kompetensi Inti (KI), Komputer Dasar (KD), Indikator Pencapaian Kompetensi (IPK) dan materi pokok pada semester ganjil yang dikembangkan ke dalam media pembelajaran e-learning. Hasil Analisis Karakteristik Pembelajaran pada mata pelajaran Informatika dengan berdasar pada hasil angket dikatakan peserta didik merasa bosan dengan metode mengajar guru yang selalu menggunakan metode konvensional. Pembelajaran dengan menggunakan metode konvensional berlangsung secara klasikal dan berpusat pada guru (teacher center). Pembelajaran ini lebih mengutamakan hasil dari pada proses. Untuk hasil analisis sumber belajar, diketahui bahwa guru menggunakan buku paket, LKS, dan internet sebagai referensi dari materi pelajaran informatika. Selain itu minimnya referensi terkait mata pelajaran Informatika untuk peserta didik dikarenaka mata pelajaran ini terbilang baru diterapkan pada tahun 2019 kemarin.

\section{Hasil Tahap Perancangan (Design)}

Pada tahap perancangan (design) dilakukan merancang desain rencana pelaksanaan pembelajaran (RPP), desain konten media pembelajaran e-learning dan desain media pembelajaran e-learning. Tahap desain penyusunan rencana pelaksanaan pembelajaran (RPP) dalam proses pembelajaran informatika menyesuaikan dengan tahapan dari model pembelajaran Flipped Classroom pada bagian kegiatan inti pembelajaran dan mengikuti format kurikulum 2013 sebagai pedoman dalam proses pembelajaran di SMP Negeri 2 Mengwi. Pada bagian pertama RPP memuat identitas sekolah, mata pelajaran, kelas/semester, dan alokasi waktu, kemudian memuat kompetensi dasar yang merupakan kemampuan mencapai kompetensi inti yang harus dicapai peserta didik, selanjutnya pertemuan pada RPP yang terdapat kegiatan pendahuluan, kegiatan inti dan kegiatan penutup. Pada bagian selanjutnya terdapat Teknik penilaian, instrument penilaian dan pada tahap terakhir pada baian RPP memuat media, alat dan sumber belajar yang digunakan dalam proses pembelajaran informatika.

Tahap perancangan konten dari media pembelajaran e-learning dilakukan dengan perancangan bahan ajar untuk materi pada mata pelajaran informatika yang disesuaikan dengan analisis kebutuhan konten pada media pembelajaran e-learning. Kegiatan pada tahapan perancangan konten pembelajaran difokuskan pada pembuatan konten pembelajaran dalam bentuk modul, gambar, dan video pembelajaran. Hasli dari tahapan perencanaan yang peneliti lakukan akan dijabarkan sebagai berikut:

Perancangan untuk gambar pembelajaran dibuat dengan gambar ilustrasi yang berisi rangkuman dari materi pembelajaran yang dirancang dalam bentuk sketsa gambar kemudian diisi dengan keterangan berupa informasi yang akan dimasukan ke dalam gambar.

Perancangan untuk modul pembelajaran dibuat dalam bentuk draft modul. Berikut merupakan urutan draft dari modul pembelajaran pada mata pelajaran informatika yaitu berisi halaman Sampul, Kompetensi Dasar, Indikator Pencapaian Kompetensi, Materi Pembelajaran dan Daftar Pustaka.

Perancangan untuk video pembelajaran dikembangkan dalam bentuk skenario video materi dan video tutorial yang disesuaikan dengan kompetensi dasar 3.2 dan 4.2 yang terdapat dalam silabus mengenai materi analisis data.

Pada tahap perancangan Media pembelajaran $e$ learning peneliti mengembangkan media menggunakan platform edmodo berbasis web. Peneliti membuat perancangan terhadap struktur menu untuk alur kegiatan proses pembelajaran dengan rancangan fitur-fitur yang digunakan pada e-learning. Struktur menu pada e-learning menggunakan platform edmodo terdiri dari tiga menu utama yaitu login, home, dan kelas. Adapun hasil perancangan struktur menu pada media e-learning yang dirancang menggunakan platform edmodo yaitu dapat dilihat pada gambar 2 .

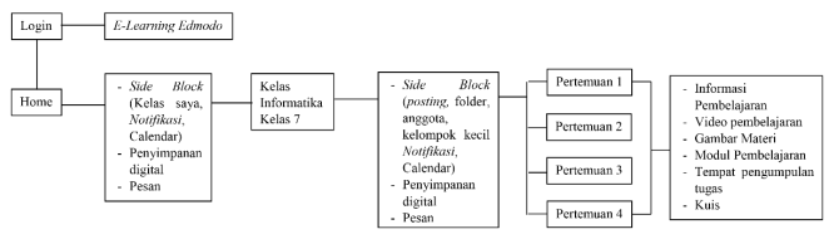

Gambar 2. Perancangan Struktur Menu Media E-Learning

\section{Hasil Tahap Pengembangan (Development)}

Tahap pengembangan dilakukan dengan 2 tahapan pembuatan produk yaitu tahap pengembangan konten pembelajaran dan tahap pengembangan media pembelajaran e-learning Informatika. Pada tahap pengembangan konten pembelajaran dilakukan dengan cara pengumpulan materi/bahan ajar, dari beberapa sumber buku/e-book, dan dari situs resmi kemendikbud berupa paket unit pemberajaran Informatika. Semua penyusunan tersebut diimplementasikan ke dalam platform edmodo. konten-konten yang dikembangkan disesuaikan dengan materi pembelajaran yang ada pada silabus. Proses pembuatan konten pembelajaran, oleh peneliti menggunakan bantuan beberapa software seperti: Adobe After Efects, aplikasi Free Screen Video Recorder, Adobe Primier CS6, Adobe dan Adobe Photoshop CS6. Adapun hasil tahapan pengembangan (development) konten yang dibuat yaitu:

Hasil dari pengembangan video pembelajaran dapat dilihat pada tabel 5 . 
e-ISSN: 2685-7006|p-ISSN: $2252-9063$

Kumpulan Artikel Mahasiswa Pendidikan Teknik Informatika

(KARMAPATI)

Volume 10, Nomor 1,Tahun 2021

KคRMดPดTI

Tabel 5.Hasil Pengembangan Video Pembelajaran

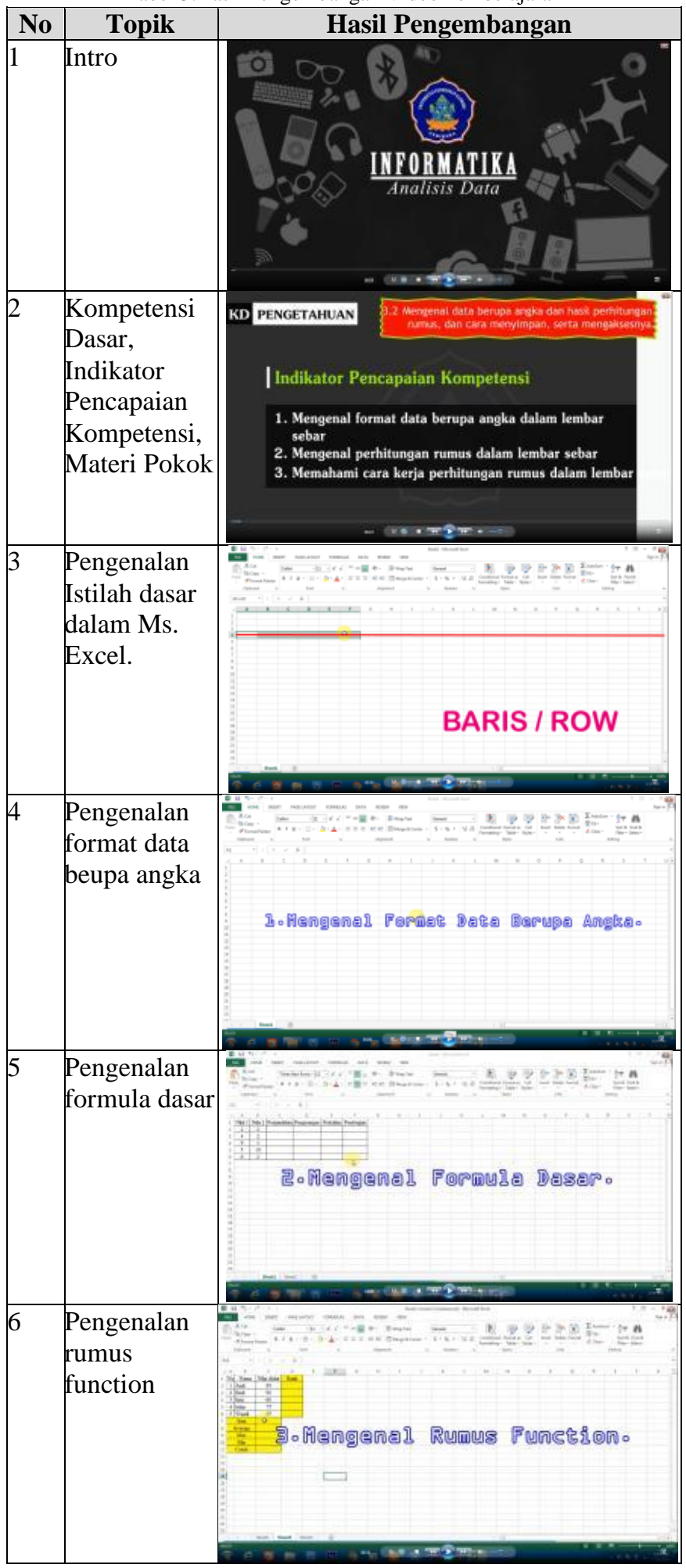

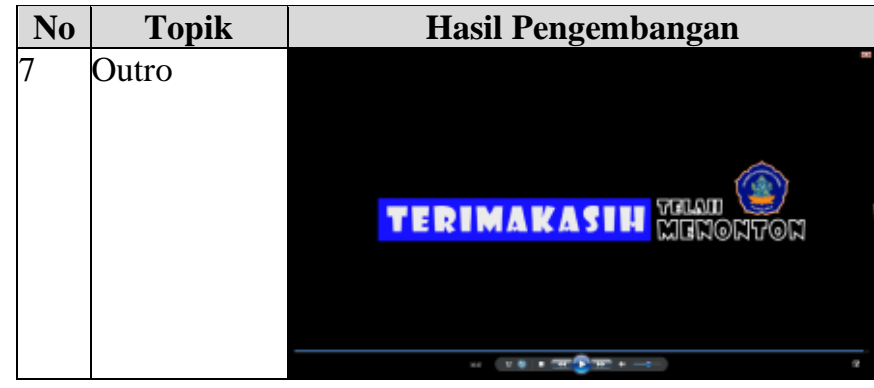

Hasil dari pengembangan modul pembelajaran terdapat draf modul yang dikembangkan yaitu Halaman Sampul, Kompetensi Dasar, Indikator Pencapaian Kompetensi, Materi Pembelajaran dan Daftar Pustaka. Cover modul dapat dilihat pada gambar 3 .

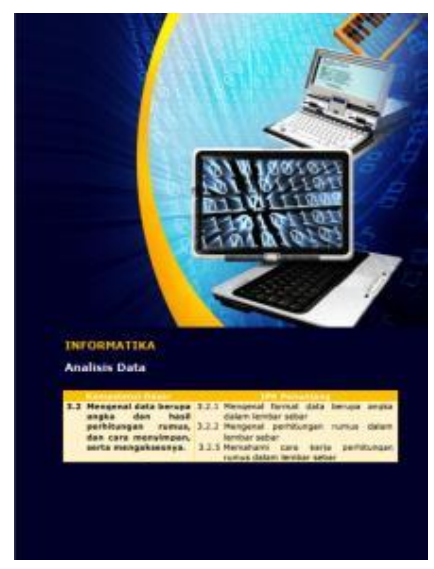

Gambar 3. Halaman Sampul

Hasil dari pengembangan gambar pembelajaran dapat dilihat pada gambar 4 .

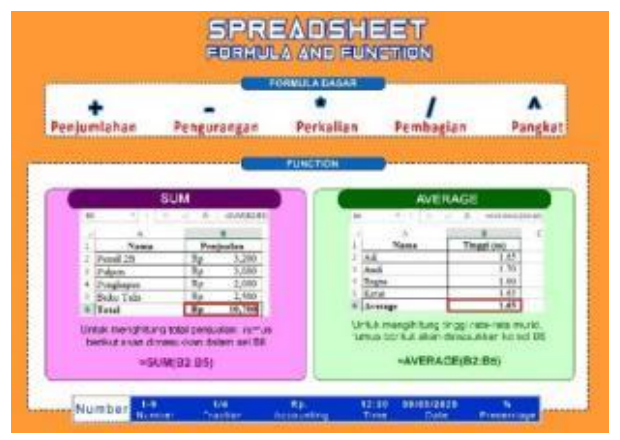

Gambar 4. Hasil Pengembangan Gambar Pembelajaran

Hasil pengembangan media pembelajaran e-learning pada mata pelajaran Informatika adalah berupa web dengan menggunakan platform LMS edmodo yang berpatokan pada model pembelajaran flipped classroom. Dimana model pembelajaran ini memiliki 3 fase pembelajaran yaitu Before class, During-Class dan After-Class Adapun fitur-fitur yang 
e-ISSN: 2685-7006|p-ISSN: $2252-9063$

Kumpulan Artikel Mahasiswa Pendidikan Teknik Informatika

(KARMAPATI)

Volume 10, Nomor 1,Tahun 2021

KดRMAPคTI

disediakan dalam media pembelajaran e-learning ini meliputi: 1) informasi mengenai materi pembelajaran, 2) informasi mengenai nilai peserta didik, 3) informasi mengenai tes/kuis, 4) melakukan komunikasi atau berdiskusi menggunakan forum yang telah disediakan, 5) informasi mengenai tugas peserta didik. Dalam pengembangan media pembelajaran e-learning mata pelajaran Informatika ini terdapat dua pengguna yaitu, guru, dan peserta didik. Berikut hasil pengembangan media pembelajaran e-learning berbasis edmodo dengan model pembelajaran flipped classroom.

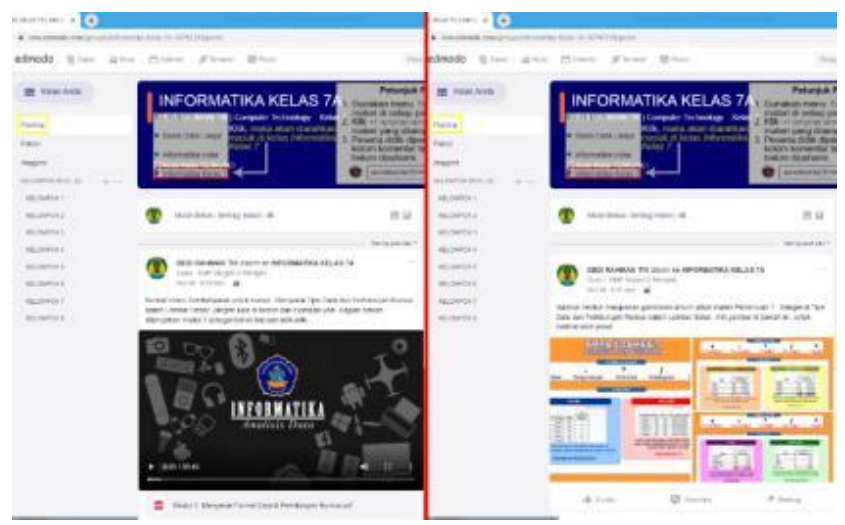

Gambar 5. Tampilan Halaman Before class

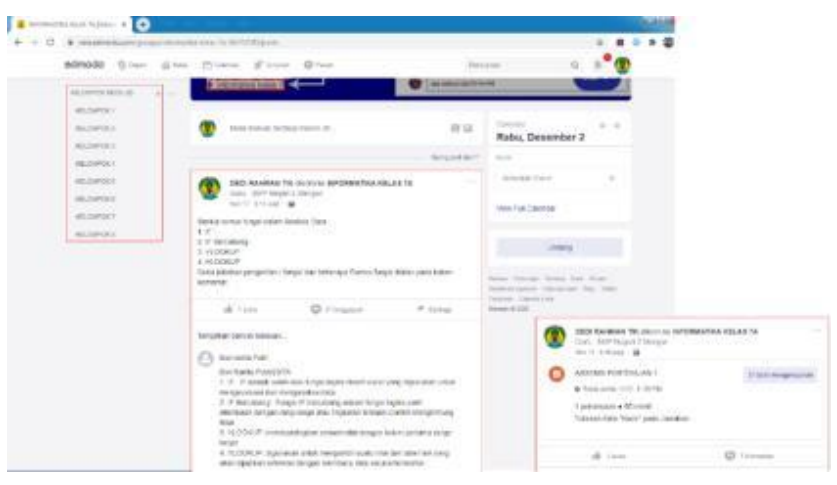

Gambar 6. Tampilan Halaman During-Class

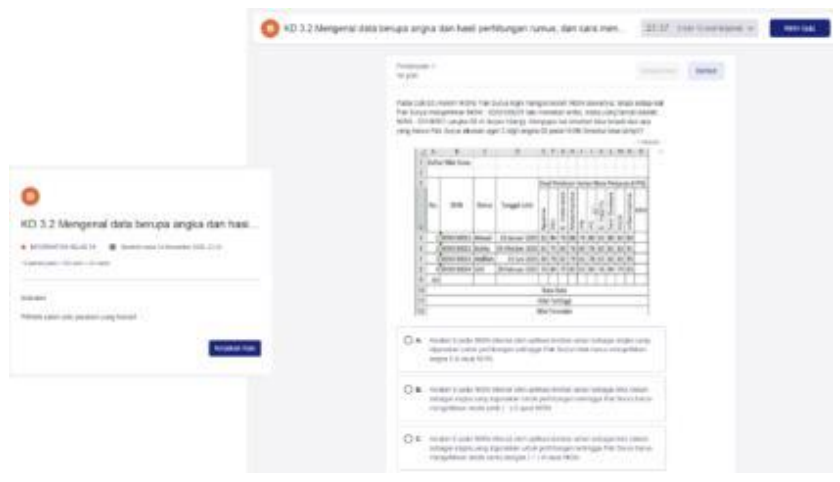

Gambar 7. Tampilan Halaman After-class

Tahapan uji ahli dilaksanakan setelah produk media pembelajaran e-learning pada mata pelajaran Informatika selesai dikembangkan, maka tahap selanjutnya peneliti melakukan uji ahli untuk meningkatkan kualitas dari produk media pembelajaran e-learning yang telah dihasilkan. Dalam hal ini peneliti melakukan tahapan validasi ahli yang terdiri dari ahli isi Pembelajaran, ahli desain pembelajaran dan ahli media pembelajaran.

a). Ahli Isi Pembelajaran

Pada uji ahli isi terbagi menjadi 2 tahap yaitu tahap pertama dan tahap kedua. Untuk uji ahli isi tahap pertama bertujuan untuk mendapatkan saran perbaikan dan revisi terhadap isi materi pada media pembelajaran e-learning, dan peneliti menindaklanjuti dari uji tahap pertama dengan melakukan revisi. . Pada uji ahli isi tahap pertama yang telah dilakukan berada pada kriteria "Sangat Valid" dengan koefisien indeks aiken sebesar 0,81 sehingga peneliti melakukan perbaikan terkait revisi terhadap isi media pembelajaran e-learning. Setelah melakukan revisi peneliti melakukan uji ahli isi tahap kedua. Mencermati hasil perhitungan indeks aiken tahap 2 dari setiap butir pertanyaan, diperoleh hasil semua butir berada pada kategori valid atau sangat valid, karena indeks terendah 0,75 dan yang tertinggi 1,00. Selanjutnya hasil perhitungan validitas dikonversikan dengan tabel kriteria tingkat validitas yang ada pada tabel 2 . Hasil menunjukkan bahwa koefisien indeks aiken rata-rata mengalami kenaikan menjadi 0,91 berada pada tingkat "Sangat Tinggi". Hal tersebut menyatakan isi pembelajaran yang ada pada media pembelajaran e-learning berbasis edmodo sudah "Sangat Valid" dan layak untuk digunakan dalam pembelajaran Informatika.

b). Ahli Desain Pembelajaran

Pada uji ahli desain terbagi menjadi 2 tahap yaitu tahap pertama dan tahap kedua. Untuk uji ahli desain tahap pertama bertujuan untuk mendapatkan saran perbaikan dan revisi terhadap desain materi pada media pembelajaran $e$ learning, dan peneliti menindaklanjuti dari uji tahap pertama dengan melakukan revisi. Pada uji ahli desain tahap pertama yang telah dilakukan berada pada kriteria "Valid" dengan koefisien indeks Aiken sebesar 0,80 sehingga peneliti melakukan perbaikan terkait revisi terhadap desain media pembelajaran e-learning. Setelah melakukan revisi peneliti melakukan uji ahli desain tahap kedua. Mencermati hasil perhitungan indeks aiken tahap 2 dari setiap butir pertanyaan, diperoleh hasil semua butir berada pada kategori valid atau sangat valid, karena indeks terendah 0,75 dan yang tertinggi 0,88 . Selanjutnya hasil perhitungan validitas dikonversikan dengan tabel kriteria tingkat validitas yang ada pada tabel 2 . Hasil menunjukkan bahwa koefisien indeks aiken rata-rata mengalami kenaikan menjadi 0,83 berada pada tingkat "Sangat Tinggi". Hal tersebut menyatakan desain pembelajaran yang ada pada media pembelajaran e-learning berbasis edmodo sudah "Sangat Valid" dan layak untuk digunakan dalam pembelajaran Informatika.

c). Ahli Media Pembelajaran 
Pada uji ahli media terbagi menjadi 2 tahap yaitu tahap pertama dan tahap kedua. Untuk uji ahli media tahap pertama bertujuan untuk mendapatkan saran perbaikan dan revisi terhadap media materi pada media pembelajaran e-learning, dan peneliti menindaklanjuti dari uji tahap pertama dengan melakukan revisi. . Pada uji ahli media tahap pertama yang telah dilakukan berada pada kriteria "Sangat Valid" dengan koefisien indeks Aiken sebesar 0,92 sehingga peneliti melakukan perbaikan terkait revisi terhadap media pembelajaran e-learning. Setelah melakukan revisi peneliti melakukan uji ahli media tahap kedua. Mencermati hasil perhitungan indeks aiken tahap 2 dari setiap butir pertanyaan, diperoleh hasil semua butir berada pada kategori valid atau sangat valid, karena indeks terendah 0,75 dan yang tertinggi 1,00. Selanjutnya hasil perhitungan validitas dikonversikan dengan tabel kriteria tingkat validitas yang ada pada tabel 2 . Hasil menunjukkan bahwa koefisien indeks aiken rata-rata mengalami kenaikan menjadi 0,94 berada pada tingkat "Sangat Tinggi". Hal tersebut menyatakan aspek media pembelajaran e-learning berbasis edmodo sudah "Sangat Valid" dan layak untuk digunakan dalam pembelajaran Informatika.

4. Hasil Tahap Implementasi (Implementation)

a). Hasil Validasi Uji Coba Perorangan

Uji coba perorangan dilakukan terhadap 3 orang peserta didik kelas VII A. Dari hasil angket uji coba perorangan yang telah di isi oleh masing masing responden, 1 orang peserta didik memberikan tanggapan sangat baik $(33,33 \%)$, dan 2 orang peserta didik memberikan tanggapan baik $(66,67 \%)$, dan tidak ada responden yang memberikan tanggapan cukup, kurang dan sangat kurang. Selanjutnya dari hasil angket uji perorangan memperoleh jumlah skor penilaian keseluruhan subjek sebesar 260, dari skor tersebut dilakukan perhitungan persentase tingkat pencapaian keseluruhan subjek sejumlah $87 \%$ jika dikategorikan kedalam tabel konversi termasuk dalam kategori "Baik". Hal ini menunjukan bahwa media pembelajaran e-learning pada mata pelajaran Informatika tidak perlu direvisi, karena sudah berada pada kriteria "Valid" dan layak untuk diterapkan yang dibuktikan dengan terbantunya peserta didik dalam memahami materi pada mata pelajaran informatika serta mempermudah dalam proses pembelajaran, salah satunya dengan mengatasi masalah dalam hal perolehan sumber belajar. Berikut hasil dari uji coba perorangan dapat dilihat pada tabel 6 .

Tabel 6. Rekapitulasi Penilaian Pada Uji Coba Perorangan

\begin{tabular}{|c|c|c|}
\hline $\begin{array}{c}\text { Konversi tingkat } \\
\text { pencapaian }\end{array}$ & $\begin{array}{c}\text { Persentase } \\
(\%)\end{array}$ & $\begin{array}{c}\text { Jumlah } \\
\text { Responden } \\
\text { (orang) }\end{array}$ \\
\hline Sangat Baik & $33,33 \%$ & 1 \\
\hline Baik & $66,67 \%$ & 2 \\
\hline Cukup & $0 \%$ & 0 \\
\hline Kurang & $0 \%$ & 0 \\
\hline
\end{tabular}

\begin{tabular}{|c|c|c|}
\hline $\begin{array}{c}\text { Konversi tingkat } \\
\text { pencapaian }\end{array}$ & $\begin{array}{c}\text { Persentase } \\
(\%)\end{array}$ & $\begin{array}{c}\text { Jumlah } \\
\text { Responden } \\
\text { (orang) }\end{array}$ \\
\hline Sangat Kurang & $0 \%$ & 0 \\
\hline
\end{tabular}

Uji Coba Perorangan

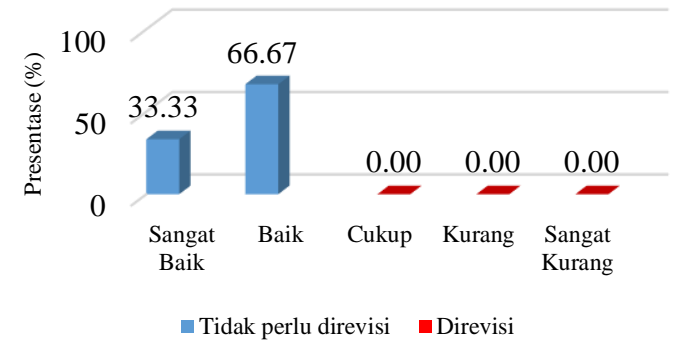

Gambar 9. Grafik Rekapitulasi Uji Coba Perorangan

\section{b). Hasil Validasi Uji Coba Kelompok Kecil}

Uji coba kelompok kecil dilakukan terhadap 10 orang peserta didik kelas VII A. Dari hasil angket uji coba kelompok kecil yang telah di isi oleh masing masing responden, 4 orang peserta didik memberikan tanggapan sangat baik $(40 \%)$, dan 6 orang peserta didik memberikan tanggapan baik (60\%), dan tidak ada responden yang memberikan tanggapan cukup, kurang dan sangat kurang. Selanjutnya dari hasil angket uji coba kelompok kecil diperoleh jumlah skor penilaian keseluruhan subjek sebesar 900, dari skor tersebut dilakukan perhitungan persentase tingkat pencapaian keseluruhan subjek sejumlah 90\% jika dikategorikan kedalam tabel konversi termasuk dalam kategori "Sangat Baik". Hal ini menunjukan bahwa media pembelajaran e-learning pada mata pelajaran Informatika tidak perlu direvisi, karena sudah berada pada kriteria "Sangat Valid" dan layak untuk diterapkan yang dibuktikan dengan peserta didik dalam memahami materi pada mata pelajaran Informatika dan media pembelajaran e-learning juga mempermudah peserta didik untuk memperolehan sumber belajar. Berikut hasil dari uji coba kelompok kecil dapat dilihat pada tabel 7 .

Tabel 7. Rekapitulasi Penilaian Pada Uji Coba Kelompok Kecil

\begin{tabular}{|c|c|c|}
\hline $\begin{array}{c}\text { Konversi tingkat } \\
\text { pencapaian }\end{array}$ & $\begin{array}{c}\text { Persentase } \\
(\%)\end{array}$ & $\begin{array}{c}\text { Jumlah } \\
\text { Responden } \\
\text { (orang) }\end{array}$ \\
\hline Sangat Baik & $40 \%$ & 4 \\
\hline Baik & $60 \%$ & 6 \\
\hline Cukup & $0 \%$ & 0 \\
\hline Kurang & $0 \%$ & 0 \\
\hline Sangat Kurang & $0 \%$ & 0 \\
\hline
\end{tabular}




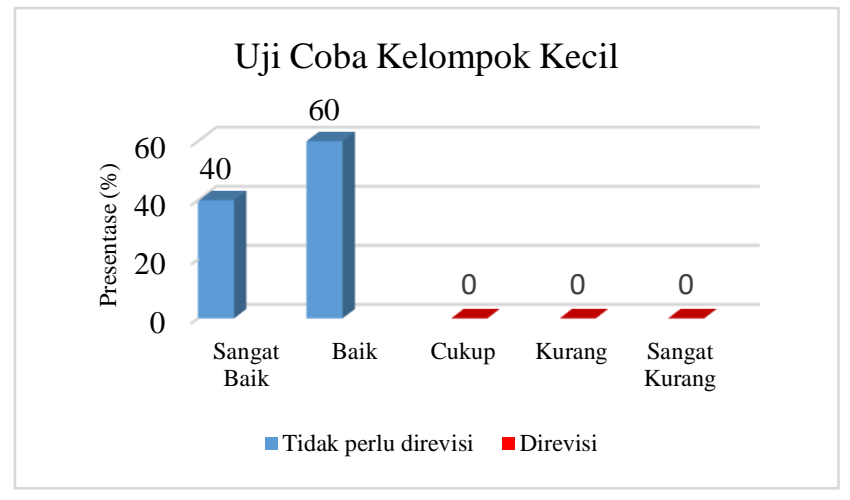

Gambar 8. Grafik Rekapitulasi Uji Coba Kelompok Kecil

\section{c). Hasil Validasi Uji Coba Lapangan}

Uji coba coba lapangan dilakukan terhadap 30 orang peserta didik kelas VII A. Dari hasil angket uji coba lapangan yang telah di isi oleh masing masing responden, 3 orang peserta didik memberikan tanggapan sangat baik (10\%), dan 27 orang peserta didik memberikan tanggapan baik (90\%), dan tidak ada responden yang memberikan tanggapan cukup, kurang dan sangat kurang. Selanjutnya dari hasil angket uji coba lapangan memperoleh jumlah skor penilaian keseluruhan subjek sebesar 2533, dari skor tersebut dilakukan perhitungan persentase tingkat pencapaian keseluruhan subjek sejumlah $84,4 \%$ jika dikategorikan kedalam tabel konversi termasuk dalam kategori "Baik". Hal ini menunjukan bahwa media pembelajaran e-learning pada mata pelajaran Informatika tidak perlu direvisi, karena sudah berada pada kriteria "Valid" dan layak untuk diterapkan yang dibuktikan dengan terbantunya peserta didik dalam memahami materi pada mata pelajaran informatika dan mendia pembelajaran e-learning juga mempermudah peserta didik untuk memperolehan sumber belajar. Berikut hasil dari uji coba lapangan dapat dilihat pada tabel 8 .

Tabel 8. Rekapitulasi Penilaian Pada Uji Coba Lapangan

\begin{tabular}{|c|c|c|}
\hline $\begin{array}{c}\text { Konversi tingkat } \\
\text { pencapaian }\end{array}$ & $\begin{array}{c}\text { Persentase } \\
(\%)\end{array}$ & $\begin{array}{c}\text { Jumlah } \\
\text { Responden } \\
\text { (orang) }\end{array}$ \\
\hline Sangat Baik & $10 \%$ & 3 \\
\hline Baik & $90 \%$ & 27 \\
\hline Cukup & $0 \%$ & 0 \\
\hline Kurang & $0 \%$ & 0 \\
\hline Sangat Kurang & $0 \%$ & 0 \\
\hline
\end{tabular}

\section{Uji Coba Lapangan}

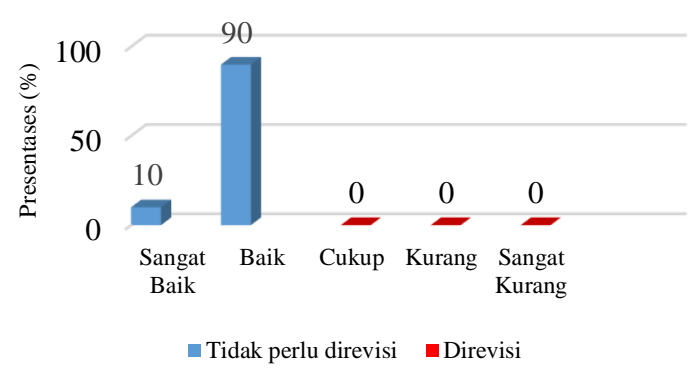

Gambar 10. Grafik Rekapitulasi Uji Coba Lapangan

d). Hasil Uji Respon Peserta Didik

Dari hasil penilaian uji respons peserta didik yang telah dilakukan dengan 30 orang responden, dengan jumlah skor responden sebesar 1855, dari skor tersebut dilakukan perhitungan rata-rata kelas $(\bar{x})$ dari respon sehingga mendapatkan nilai sebesar 61,8 jika dikategorikan kedalam tabel konversi penggolongan respons hasilnya termasuk dalam rentangan kualifikasi "Sangat Positif" dengan mecapai kriteria "Sangat Praktis". Hal ini menunjukkan bahwa pengembangan media pembelajaran e-learning pada mata pelajaran informatika berhasil dikembangkan, yang dibuktikan dengan hasil komentar angket seperti peserta didik merasa senang belajar menggunakan edmodo yang bisa mempurmudah untuk melihat materi yang berkaitan dengan pelajaran informatika.

\section{e). Hasil Uji Respon Guru}

Dari hasil penilaian uji respons guru yang telah dilakukan dengan 1 orang responden, dengan jumlah skor responden sebesar 40, dari skor tersebut dilakukan perhitungan rata-rata kelas $(\bar{x})$ dari respon sehingga mendapatkan nilai sebesar 40 jika dikategorikan kedalam tabel konversi penggolongan respons hasilnya termasuk dalam rentangan kualifikasi "Sangat Positif" dengan mecapai kriteria "Sangat Praktis". Hal ini menunjukkan bahwa pengembangan media pembelajaran e-learning mata pelajaran informatika berhasil dikembangkan, yang dibuktikan dengan hasil komentar angket yang menunjukan respon positif dari guru seperti penggunaan media pembelajaran $e$-learning ini sangat bagus dan mempermudah pembelajaran untuk guru.

\section{Hasil Tahap Evaluasi (Evaluation)}

Dari keseluruhan aspek terkait perlaksanaan evaluasi setiap tahapan model pengembangan ADDIE, semuanya sudah diterapkan dengan berpatokan pada masing-masing instrument dari setiap indicator penilaian.

Validitas media pembelajaran e-learning dengan model pembelajaran flipped classroom Berbasis Edmodo pada Mata Pelajaran Informatika didapatkan setelah melakukan uji ahli isi, uji ahli desain, dan uji ahli media. 
Hasil perhitungan dari uji ahli isi, uji ahli desain dan uji ahli media diperoleh hasil rata-rata dari pengujian validitas ahli yang dapat dilihat pada tabel 9.

Tabel 9. Rata-rata Pengujian Validitas

\begin{tabular}{|l|c|}
\hline \multicolumn{1}{|c|}{ Pengujian Ahli } & Hasil Perhitungan \\
\hline Ahli Isi & 0,91 \\
\hline Ahli Media & 0,94 \\
\hline Ahli Desain & 0,83 \\
\hline Rata-rata & 0,89 \\
\hline
\end{tabular}

Berdasarkan rata-rata nilai koefisien Aiken's V dari hasil perhitungan uji validitas ahli mendapatkan hasil 0,89 jika dikonversikan kriteria tingkat validitas uji ahli menunjukan kriteria "Sangat Tinggi", maka dari itu analisis hasil perhitungan validasi ahli tersebut dapat dikatakan media pembelajaran e-learning pada mata pelajaran informatika sudah berada pada kriteria "Sangat Valid" dan layak digunakan dalam proses pembelajaran informatika.

Kepraktisan media pembelajaran e-learning didapatkan dari hasil uji respons peserta didik dan uji respons guru. Hasil perhitungan uji respons guru diperoleh nilai $\bar{x}$ sebesar 40, mendapatkan kriteria "Sangat Praktis". Sedangkan hasil perhitungan uji respons peserta didik diperoleh nilai $\bar{x}$ sebesar 61,8, mendapatkan kriteria "Sangat Praktis". Dari analisis hasil perhitungan uji respons guru dan uji respons peserta didik tersebut, maka jika dilihat dari tabel kepraktisan maka dapat disimpulkan bahwa media pembelajaran e-learning pada mata pelajaran informatika berada pada kualifikasi "Sangat Positif" dengan kriteria "Sangat Praktis".

\section{A. Pembahasan}

Pengembangan media pembelajaran e-learning dengan model pembelajaran Flipped Classroom berbasis edmodo pada mata pelajaran Informatika kelas VII di SMP Negeri 2 Mengwi memiliki tujuan untuk dapat meningkatkan pemahaman dan pengetahuan peserta didik serta dapat membantu menambah bahan belajar bagi peserta didik serta bahan ajar bagi guru mata pelajaran informatika. Berdasarkan hasil observasi, wawancara dan penyebaran angket yang telah dilakukan di SMP Negeri 2 Mengwi pada mata pelajaran informatika, diperoleh informasi bahwa kurangnya inovasi guru dalam mengembangkan media pembelajaran informatika, hal ini terlihat dari penggunaan media pembelajaran oleh guru yang masih menggunakan media power point. Selain itu, peserta didik merasa bosan terhadap media pembelajaran yang digunakan oleh guru dalam menyampaikan suatu materi.

Penelitian ini menggunakan model pengembangan ADDIE (analyze, design, development, implementation, dan evaluation) sesuai dengan tahapan dari model pengembangan ADDIE, maka tahapan pertama yang dilakukan yaitu tahap analisis (analyze). Pada tahapan ini dilakukan kegiatan analisis karakteristik peserta didik, analisis mata pelajaran, analisis sumber belajar, dan analisis karakteristik pembelajaran. Tahap kedua adalah perancangan (design), pada tahap perancangan peneliti melakukan perancangan terhadap rencana pelaksanaan pembelajaran (RPP) dan merancang desain media pembelajaran e-learning yang disesuikan dengan kebutuhan hasil pada tahap analisis, hal tersebut peneliti melakukan pemetaan materi yang akan dikembangkan dengan menetukan Kompetensi Inti (KI) dan Kompetensi Dasar (KD) dan Indikator Pencapaian Kompetensi (IPK). Selanjutnya tahap pengembangan (development), tahap ini merupakan kegiatan yang dilakukan setelah tahap perancangan, dimana pada tahap ini kegiatan yang dilakukan yaitu kegiatan pengembangan konten pembelajaran berupa modul pembelajaran gambar materi, video materi dan video tutorial pembelajaran serta dilakukan pengembangan terhadap media pembelajaran e-learning. Tahap keempat yaitu implementasi (implementation), pada tahap implementasi peneliti melakukan uji coba produk media pembelajaran e-learning yang telah peneliti kembangkan kepada peserta didik. Pada Proses implementasi, terdapat beberapa penyesuaian diantaranya pada saat proses pembelajaran During Class/tatap muka (offline activity) yang semulanya dirancang melalui pertemuan tatap muka dialihkan dengan menggunakan sistem belajar online/daring, hal ini mengacu pada Surat Edaran Nomor 15 tahun 2020 dari Kementerian Penididikan dan Kebudayaan tentang Pedoman Penyelenggaraan Belajar dari Rumah dalam Masa Darurat Penyebaran Corona Virus Disease (COVID-19). Tahap kelima yaitu tahap evaluasi dilakukan pada pembahasan revisi masing-masing tahap pengembangan model ADDIE yang bertujuan untuk mengetahui ketercapaian dari masing-masing tahapan. Untuk ketercapaian evaluasi pada tahap implementasi dapat diketahui dari tingkat validitas, dan kepraktisan pada media pembelajaran e-learning pada mata pelajaran informatika yang telah dikembangkan.

Berdasarkan hasil validitas uji ahli diperoleh rata-rata nilai koefisien Aiken's V sebesar 0,89 menunjukan tingkat validitas "Sangat Tinggi" dengan kriteria "Sangat Valid" dan layak digunakan dalam proses pembelajaran informatika. Validitas produk ini didapatkan setelah melalui tahapan uji ahli isi, uji ahli desain, dan uji ahli media yang masingmasing dilakukan 2 kali tahapan, hal ini bertujuan untuk mengetahui peningkatan pengembangan produk yang dilakukan peneliti [14] sehingga pada uji ahli tahap 2 diperoleh hasil keseluruhan dari ketiga aspek uji ahli semuanya berada pada kriteria "Sangat Valid". Ketika pelaksanaan validitas uji ahli, peneliti telah melakukan banyak revisi terhadap produk media pembelajaran $e$ learning sesuai dengan kritikan dan masukan dari para pakar. Validitas produk ini dilakukan oleh beberapa pakar atau tenaga ahli yang sudah memiliki pengalaman untuk menilai kelemahan dan kekurangan produk yang dihasilkan agar suatu produk dapat digunakan sesuai dengan tujuannya. Selain itu, dalam proses pengembangan media pembelajaran 
e-learning peneliti juga meninjau dari kebutuhan peserta didik berdasarkan hasil observasi awal yang telah dilakukan.

Pada hasil uji coba perorangan, kelompok kecil, dan lapangan diperoleh hasil dari ketiga komponen uji coba berada pada kategori "baik" atau "sangat baik" dengan kriteria "valid" atau "sangat valid", karena nilai presentase keseluruhan subjek terendah $84,4 \%$ untuk uji coba perorangan, $87 \%$ untuk uji coba kelompok kecil dan yang tertinggi $90 \%$ untuk uji lapangan. Apabila dilihat dari tabel tingkat pencapaian dengan Skala 5 [11] maka rentang nilai presentase $75 \%$ - $89 \%$ berada pada kualifikasi baik dan nilai presentase $90 \%$ - $100 \%$ berada pada kualifikasi sangat baik. Hal ini sangat relevan dengan komentar peserta didik yang mengatakan media $e$-learning sangat membantu peserta didik dalam memperoleh materi, pengerjaan tugas, dan lebih mudah dipahami.Oleh karena itu, media pembelajaran $e$ learning berbasis edmodo tidak perlu direvisi kembali. Adapun aspek yang dinilai yaitu penyajian materi, interaktivitas, tampilan, dan pembelajaran .

Selanjutnya pada uji kepraktisan media pembelajaran e-learning didapat dari hasil perhitungan uji respons peserta didik dan respons guru. Adapun indicator yang dinilai dari uji respon yaitu kemudahan menggunakan media pembelajaran e-learning, antusias peserta didik, pengajaran menggunakan media e-learning, kemenarikan tampilan, kemudahan menggunakan media pembelajaran e-learning, motivasi terhadap peserta didik, dan isi konten. Hasil dari kedua uji respon ini diperoleh kualifikasi respon "Sangat positif", di mana perhitungan uji respons guru diperoleh nilai sebesar 40 dengan kriteria "Sangat Praktis" dan hasil perhitungan uji respons peserta didik diperoleh nilai sebesar 61,8 dengan kriteria "Sangat Praktis". Hal ini diperkuat dari hasil evaluasi peserta didik keseluruhan semuanya berada di atas KKM. Selain itu, guru juga memberikan komentar bahwa media pembelajaran e-learning sudah sangat bagus dan mempermudah pembelajaran untuk guru maupun peserta didik. Hal tersebut menunjukan bahwa peserta didik sangat antusias dan termotivasi serta mendukung adanya pengembangan media pembelajaran e-learning pada mata pelajaran informatika..

Kelebihan dari media pembelajaran e-learning informatika dengan menggunakan platform LMS Edmodo, yakni: 1). Media pembelajaran e-learning mempermudah peserta didik dalam belajar secara mandiri karena materi dapat diakses secara berulang-ulang, kapan saja dan dimana saja, 2). Media pembelajaran e-learning dapat mempermudah peserta didik dalam mempelajari materi dalam kondisi nyaman sesuai dengan kemampuanya dalam menerima materi, 3). Media pembelajaran e-learning pada mata pelajaran informatika menambah semangat dan motivasi peserta didik dalam belajar, 4). Adanya media pembelajaran e-learning mempermudah guru dan peserta didik dalam berkomunikasi melalui fasilitas internet tanpa di batasi oleh jarak, tempat dan waktu
Kendala yang peneliti temui selama melakukan pengembangan serta selama proses implementasi media yaitu, 1). Akses jaringan ditempat tinggal peneliti kurang terjangkau sehingga beberapa kali mempersulit untuk berkomunikasi dengan dosen maupun guru. 2). Mengacu dengan Surat Edaran Nomor 15 tahun 2020 dari Kementerian Penididikan dan Kebudayaan tentang Penyelenggaraan Belajar dari Rumah dalam Masa Darurat Penyebaran Corona Virus Disease (COVID-19) menyebabkan pembelajaran tatap muka di rubah menjadi pembelajaran daring/online, yang mana terdapat beberapa peserta didik yang memiliki kesulitan untuk mengakses edmodo karena belum pernah menggunakan edmodo. 3). yaitu kuota internet yang dimiliki peserta didik maupun bantuan dari kemendikbud terbatas menyebabkan peserta didik tidak dapat digunakan untuk terus menonton video maupun dalam mengakses internet karena kebanyakan peserta didik hanya memiliki kuota chat. Selain itu, kuota internet dari kemendikbud-pun terbatas karena lebih banyak dialokasikan untuk kuota multimedia yang hanya bisa diakses pada beberapa platform seperti zoom, ruang guru, ilmu pedia, dan lain-lain.

\section{PENUTUP}

Berdasarkan hasil penelitian dan pembahasan pada penelitian Pengembangan Media Pembelajaran E-Learning dengan Model Pembelajaran Flipped Classroom Berbasis Edmodo pada Mata Pelajaran Informatika Kelas VII di SMP Negeri 2 Mengwi, maka peneliti dapat menarik beberapa kesimpulan sebagai berikut:

Hasil pengembangan dan implementasi Media Pembelajaran E-Learning Dengan Model Pembelajaran Flipped Classroom Berbasis Edmodo pada Mata Pelajaran Informatika Kelas VII di SMP Negeri 2 Mengwi, berdasarkan hasil dari pengujian yang telah dilakukan pada ahli isi pembelajaran berada pada kriteria "Sangat Valid" dengan nilai koefisien Aiken's V sebesar 0,91, kemudian pada pengujian ahli desain pembelajaran berada pada kriteria "Sangat Valid" dengan nilai koefisien Aiken's V sebesar 0,83 , serta pada pengujian ahli media pembelajaran berada pada kriteria "Sangat Valid" dengan nilai koefisien Aiken's $\mathrm{V}$ sebesar 0,94. Berdasarkan hasil respons guru terhadap Pengembangan Media Pembelajaran E-Learning Dengan Model Pembelajaran Flipped Classroom Berbasis Edmodo pada Mata Pelajaran Informatika Kelas VII di SMP Negeri 2 Mengwi, mendapatkan rata-rata sebesar 40 jika dikonversikan ke dalam tabel kriteria penggolongan respons maka hasil dari respon peserta didik berada pada kualifikasi "Sangat Positif" dengan kriteria "Sangat Praktis", sedangkan hasil respons dari guru terhadap Media Pembelajaran ELearning dengan Model Pembelajaran Flipped Classroom Berbasis Edmodo pada Mata Pelajaran Informatika Kelas VII di SMP Negeri 2 Mengwi, memperoleh hasil rata-rata sebesar 61,8 jika dikonversikan ke dalam tabel kriteria penggolongan respons mendapatkan hasil dari respon peserta 
e-ISSN: 2685-7006 | p-ISSN: $2252-9063$

Kumpulan Artikel Mahasiswa Pendidikan Teknik Informatika

(KARMAPATI)

Volume 10, Nomor 1,Tahun 2021

KดRMAPคTI

didik berada pada kualifikasi "Sangat Positif" dengan kriteria "Sangat Praktis".

\section{REFERENCES}

[1]. Suriadhi, Gede dkk. (2014). Pengembangan E-Learning Berbasis Edmodo Pada Mata Pelajaran IPA Kelas VIII di SMP Negeri 2 Singaraja. volume 2, No 1 (hlm 1 10).

[2]. Atmanegara, W.P \& Puput Wanarti Rusimamto. (2016). Pengembangan Media Pembelajaran E-Learning Menggunakan Edmodo Pada Mata Pelajaran Elektronika Dasar Studi Pada Siswa Kelas X Tei SMK Negeri 2 Bojonegoro. Jurnal Pendidikan Teknik Elektro, 5 (1), 359-364. Diakses dari: (https://jurnalmahasiswa.unesa.ac.id/index.php/jurnal-pendidikanteknik-elektro/article/view/14020).

[3]. Hanif, Husni Nadya et al. (2016). Perbandingan Antara Model Pembelajaran Flipped Classroom Berbantuan Edmodo Dengan Pembelajaran Konvensional Terhadap Hasil Belajar Sistem Operasi (Eksperimen Kelas X SMK 1 Banyudono). Diakses dari : (https://digilib.uns.ac.id/dokumen/detail/54537/)

[4]. Prawiradilaga, Dewi Salma dkk. 2013. Mozaik Teknologi Pendidikan: E-learning. Jakarta: Prenadamedia Group.

[5]. Sa'diyah, Halimah et al. (2016). Pengembangan Media E-Learning Berbasis Edmodo Pada Mata Pelajaran Matematika Kelas VII di SMP Muhammadiyah 3 Depok. . Diakses dari : (http://seminar.uad.ac.id/index.php/sendikmad/article/view/17/pdf).

[6]. Sukayanti, Luh Rika. 2018. Pengembangan Blended Learning Tipe Flipped Classroom Pada Mata Pelajaran Seni Budaya Kelas XI di SMK Negeri 3 Singaraja Tahun Pelajaran 2017/2018. Singaraja: Undiksha.

[7]. Tim IG TIK PGRI .(2019). Ayo Belajar Informatika Tingkat SMP Science, Technology, Engineering And Mathematics. Diakses dari : (https://drive.google.com/file/d/1p8EoPw493B9kkKhBBW5erdDV4 FW6arF_/view).

[8]. Tegeh, I M. \& Kirna, I. M. (2010). Metode Penelitian Pengembangan Pendidikan. Singaraja: Undiksha.

[9]. Rahmat \& Irfan, Dedy. (2019). Rancang Bangun Media Pembelajaran Interaktif Komputer dan Jaringan Dasar di SMK. Jurnal Vokasional
Teknik Elektronika dan Informatika, 7 (1), 48-53. Diakses dari: (http://ejournal.unp.ac.id/index.php/voteknika/article/view/103642/).

[10]. Rahmat \& Irfan, Dedy. (2019). Rancang Bangun Media Pembelajaran Interaktif Komputer dan Jaringan Dasar di SMK. Jurnal Vokasional Teknik Elektronika dan Informatika, 7 (1), 48-53. Diakses dari: (http://ejournal.unp.ac.id/index.php/voteknika/article/view/103642/).

[11]. Pujawan, Kadek Agus H. (2018). Pengembangan Multimedia Interaktif Berbasis Video Tutorial pada Mata Kuliah Multimedia I (Design Grafis) di Politeknik Ganesha Guru. Jurnal of Education Technology (JET). 2 (1), 61-66. Diakses dari: (https://ejournal.undiksha.ac.id/index.php/JET/article/view/13810/)

[12]. Candiasa, I M. (2011). Pengujian Instrumen Penelitian disertai Aplikasi ITEMAN dan BIGSTEPS. Singaraja: Undiksha Press.

[13]. Nurkancana, W. \& Sunartana. (1992). Evaluasi Hasil Belajar. Surabaya: Usaha Nasional.

[14]. Selibauti, Liya, et al. (2017). Pengembangan Modul Pembelajaran Menulis Puisi Berbasis Experiential Learning Untuk Siswa Kelas VIII SMP.. Diakses dari : (https://repository.unja.ac.id/1967/). 